\title{
Antitumor and Antimicrobial Potential of Manganese(II), Nickel(II) and Copper(II) Complexes of 4-Methoxy Benzohydrazide Derived Schiff Base Ligand
}

\author{
Maina Awatade 1, Panchsheela Ubale 2,3,*, Amit Kamble 4, Makarand Kulkarni 5, Dipak Gaikwad ', \\ Ravindra Veerapur ${ }^{7}$, Ghada Lamraoui ${ }^{8}$, Shiva Prasad Kollur ${ }^{\text {9,* }}$
}

1 Department of Chemistry, SVERI's College of Engineering and SVERI's College of Engineering (Poly.), Pandharpur, Solapur- 413 304, Maharashtra, India; mmawatade@ coe.sveri.ac.in (M.A.);

2 Department of Chemistry, Rajaram College, Shivaji University, Kolhapur - 416 004, Maharashtra, India

3 N. K. Orchid College of Engineering and Technology, Solapur - 413 002, Maharashtra, India

4 Bharatratna Indira Gandhi College of Engineering, Solapur - 413 002, Maharashtra, India; amit.kamble1583@ gmail.com (A.K.);

5 Scientific Instrument Centre, Punyashlok Ahilyadevi Holkar Solapur University, Solapur - 413 255, Maharashtra, India; makarand1983@gmail.com (M.K.);

6 Department of Chemistry, Vivekanand College, Kolhapur-416 004, Maharashtra, India; dgchemistry@ gmail.com (D.G.);

7 Department of Materials and Metallurgy Engineering, Malawi Institute of Technology, Malawi University of Science and Technology, P.O. Box - 5916, Limbe, Malawi; rveerapur@must.ac.mw (R.V.);

8 Nature and Life Sciences, Earth and Universe Sciences, University of Tlemcen, Tlemcen, Algeria; lamraouig@gmail.com (G.L.);

9 Department of Sciences, Amrita School of Arts and Sciences, Amrita Vishwa Vidyapeetham, Mysuru Campus, Mysuru, Karnataka-570 026, India; shivachemist@gmail.com (S.P.K.);

* Correspondence: panchsheela_ubale@rediffmail.com (P.U.); shivachemist@ gmail.com (S.P.K.);

Scopus Author ID 7004879365

Received: 1.02.2021; Revised: 15.04.2021; Accepted: 25.04.2021; Published: 27.06.2021

Abstract: Herein, we describe the synthesis and characterization of a Schiff base ligand (E)-N'-(2hydroxybenzylidene)-4-methoxybenzohydrazide (HBMB) and its $\mathrm{Mn}$ (II), $\mathrm{Ni}(\mathrm{II})$, and $\mathrm{Cu}$ (II) metal complexes $\left(\mathrm{C}_{1}-\mathrm{C}_{3}\right)$ respectively. The ligand $\mathrm{HBMB}$ was synthesized by reacting condensation of salicylaldehyde and 4-methoxy benzohydrazide in a 1:1 molar ratio. The structure of HBMB and its metal complexes $\left(\mathrm{C}_{1}-\mathrm{C}_{3}\right)$ were evaluated by using UV-Vis, FT-IR, ${ }^{1} \mathrm{H}-\mathrm{NMR}$, mass spectroscopy as well as on the basis of elemental analysis, conductivity measurements, and thermogravimetric techniques (TGA). The synthesized molecules' tumoricidal properties were performed against human breast cancer (MCF-7) and colon cancer (HT 29) cell lines. The biological results indicated that the ligand, HBMB, and metal complexes possess dose-dependent selective cytotoxicity against the tested carcinoma cells. The synthesized compounds were further evaluated for their in vitro antimicrobial activities against Gram-positive bacteria (Staphylococcus aureus), Gram-negative bacteria (Escherichia coli), and fungal strains (Aspergillus niger).

Keywords: 4-methoxy benzohydrazide; metal complexes; spectral studies; anticancer activities; antibacterial activities.

\footnotetext{
(C) 2021 by the authors. This article is an open-access article distributed under the terms and conditions of the Creative Commons Attribution (CC BY) license (https://creativecommons.org/licenses/by/4.0/).
}

\section{Introduction}

Cancer is a multifactorial, complex, and mutagenic disease with the potential to metastasize and invade [1]. Treatment methods available to combat cancer include chemotherapy, radiation therapy, surgery, and targeted therapies [2]. These methods have 
several drawbacks: high cost, fatal side effects, adverse drug reactions, high recurrence rates etc. [3]. A recent report has opened up a new era of application of metal complexes in anticancer drug design and development with the breakthrough discovery of cisplatin [4]. Transition metals exhibit variable oxidation states, which gives rise to promising pharmacological congruity [5-7]. However, single-drug therapies are often brutal for cancer treatment and may not provide long-term clinical outcomes. The applications of two or more drugs are preferable to overcome this problem for targeted treatment [8]. The applications of Schiff bases and their transition metal complexes for the synthesis of metallodrugs play a vital role in the diversity-oriented synthesis and medicinal chemistry [9-10]. The transition metal complexes have been found as specific anticancer and antimicrobial active molecules to elucidate mysterious biological processes [11].

Hydrazones are a class of azomethine groups distinguished from other family members by the presence of two interlinking nitrogen atoms. It is synthesized by the condensation reaction of hydrazide with carbonyl compounds. Introduction of $-\mathrm{C}=\mathrm{O}$ group in the hydrazide moiety is known as acyl hydrazone [12]. Antitubercular activities shown by some hydrazones are comparable to that of the drugs available to treat tuberculosis. Many hydrazone derivatives have been found to possess antimicrobial activities [13-15].

In light of this discussion, herein, we report the synthesis and characterization of $\mathrm{Mn}(\mathrm{II}), \mathrm{Ni}(\mathrm{II})$, and $\mathrm{Cu}(\mathrm{II})$ complexes using a Schiff base ligand (HBMB). The research was complemented by performing their in vitro anticancer activity against human cancer cell lines, MCF-7 and HT-29, using Sulforhodamine-B assay against the tested carcinoma cells. In vitro antimicrobial activities of the synthesized compounds were evaluated against selected microbial species.

\section{Materials and Methods}

\subsection{Materials and methods.}

4-methoxybenzohydrazide was purchased from Sigma Aldrich (CA, USA) and was used as received. Salicylaldehyde, metal salts, and solvents were commercially available on high purity and used as it is. The reaction's completion was monitored by spotting the reaction mixture using thin-layer chromatography (TLC), and the spots were visualized by UV irradiation. The melting point of the compounds was determined by the open capillary method. The IR spectra were recorded with a Perkin Elmer FT-IR spectrometer in the frequency range 4000-400 $\mathrm{cm}^{-1}$. The ${ }^{1} \mathrm{H}-\mathrm{NMR}$ spectra were recorded on Bruker AC (300 MHz for ${ }^{1} \mathrm{H}-\mathrm{NMR}$ ) spectrometer using TMS as an internal standard in DMSO- $d_{6}$ for HBMB. Chemical shifts $(\delta)$ are expressed in ppm. The ultraviolet and visible spectra of Schiff base and its complexes were recorded on Shimadzu UV-3600 electronic spectrometer using quartz cells at room temperature in the 200-1000 $\mathrm{nm}$ range. TGA curves in a nitrogen atmosphere with a heating rate of $10{ }^{\circ} \mathrm{C}$ $\min ^{-1}$, in the temperature range $25-1000{ }^{\circ} \mathrm{C}$ using platinum crucibles. Elemental analysis has been calculated on Thermo Finnigan Flash EA 1112 CHN analyzer. Mass spectra of HBMB were recorded on Agilent 7890B GC system, Agilent 5977B MSD, and Mass spectra of complexes were recorded on TOF-ES technique at $70 \mathrm{eV}$ using ESI/APCI-hybrid mass spectrometer. Molar conductivity data was recorded on conductivity meter Model No. EQ660A. Magnetic susceptibility measurements were carried out on a Sherwood Scientific Magnetic Susceptibility Balance (Model MK 1) at room temperature. The reagents required to perform in vitro anticancer Sulforhodamine B (SRB) assay such as RPMI-1640, minimum 
essential medium (MEM), 10\% fetal bovine serum, trypsin, trypan blue, ethanol, penicillin, streptomycin $(0.5 \mathrm{mg} / \mathrm{mL})$, dimethyl sulfoxide (DMSO), sulforhodamine were procured from Sigma and Hi-Media Ltd. India. Further, a stock solution of $100 \mu \mathrm{g} / \mathrm{mL}$ of all the test compounds was prepared by dissolving in $0.1 \%$ DMSO. The compounds were serially diluted and treated to the cancer cells. For cell cultures, the cells were grown and maintained in an appropriate medium, $\mathrm{pH} 7.4$, supplemented with $10 \%$ fetal bovine serum, glutamate $(2 \mathrm{mM})$, penicillin, and streptomycin $(0.5 \mathrm{mg} / \mathrm{mL})$. The cell cultures were grown in a carbon dioxide incubator (Heraeus, $\mathrm{GmbH}$, Germany) at $37^{\circ} \mathrm{C}$ with $90 \%$ humidity and $5 \% \mathrm{CO}_{2}$.

\subsection{Chemical synthesis.}

\subsubsection{Synthesis of (E)-N'-(2-hydroxybenzylidene)-4-methoxybenzohydrazide (HBMB).}

The general synthetic pathway is depicted in Scheme 1. $0.122 \mathrm{~g}(1 \mathrm{mM})$ of salicylaldehyde was dissolved in $25 \mathrm{~mL}$ of dry ethanol. To this clear solution, $0.166 \mathrm{~g}(1 \mathrm{mM})$ of 4-methoxybenzohydrazide was added slowly, which resulted in a transparent solution. The above reaction mixture was then refluxed at $70^{\circ} \mathrm{C}$ for $2 \mathrm{~h}$. The colorless precipitate obtained was filtered off, washed with ethanol ( 3 times) and vacuum dried to yield the desired product.

Yield: $72 \%$. m.p.: $148^{\circ} \mathrm{C}$. UV-Vis (DMSO, $\lambda_{\max }$ ): 298, 301, and $307 \mathrm{~nm} .{ }^{1} \mathrm{H}-\mathrm{NMR}$ (DMSO-d6, 300 MHz, ppm): $\delta 8.52$ (s, 1H, -N=CH-), 6.83-7.91 (m, 8H, Ar-H), $11.51(\mathrm{~s}, 1 \mathrm{H}$, Ar-OH), 11.86 (s, 1H, -NH), 3.82 (s, 3H, -OCH $)$. FT-IR (KBr pellet, cm $\left.{ }^{-1}\right) 3290(-\mathrm{NH}), 3415$ $(-\mathrm{OH}), 1662(\mathrm{C}=\mathrm{O}), 1618(\mathrm{C}=\mathrm{N}), 1562,1550,1535(\mathrm{C}=\mathrm{C}), 1224(\mathrm{C}-\mathrm{O})$. LCMS calculated for $\mathrm{C}_{15} \mathrm{H}_{14} \mathrm{~N}_{2} \mathrm{O}_{3}[\mathrm{M}]^{+}: 270.29$ and found is $271.98[\mathrm{M}+1]$ (Fig. S3).

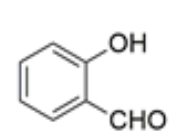

Salicyaldehyde

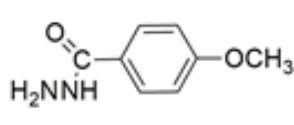

4-methoxybenzhydrazide
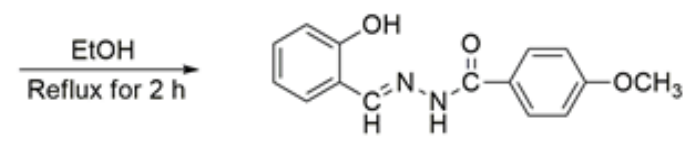

(E)- $\mathrm{N}^{\prime}$-(2-hydroxybenzylidene)-4-methoxybenzohydrazide

Scheme 1. Synthesis of (E)-N'-(2-hydroxybenzylidene)-4-methoxybenzohydrazide (HBMB).

\subsubsection{Synthesis of Metal Complexes (C1-C3).}

To an ethanolic solution ( $25 \mathrm{~mL}$ ) of appropriate metal salts $\left(1 \mathrm{mM}\right.$ of $\mathrm{MnCl}_{2} .2 \mathrm{H}_{2} \mathrm{O}(125$ $\mathrm{mg}$ ) or $\mathrm{NiCl}_{2} .6 \mathrm{H}_{2} \mathrm{O}(237 \mathrm{mg})$ or $\mathrm{CuCl}_{2} \cdot 2 \mathrm{H}_{2} \mathrm{O}(170 \mathrm{mg})$, solution of HBMB in ethanol $(25 \mathrm{~mL})$ $(1 \mathrm{mM}, 270 \mathrm{mg}$ ) was added in 1:1 (M:L) molar ratio. The resultant mixture was continuously stirred and refluxed for $6 \mathrm{~h}$ at $65^{\circ} \mathrm{C}$. The product obtained was filtered off, washed with ethanol, and dried under vacuum over $\mathrm{CaCl}_{2}$. The molecular formula of the obtained complexes: $\mathrm{C}_{1}: \mathrm{C}_{30} \mathrm{H}_{26} \mathrm{MnN}_{4} \mathrm{O}_{6} ; \mathrm{C}_{2}: \mathrm{C}_{30} \mathrm{H}_{26} \mathrm{~N}_{4} \mathrm{NiO}_{6} ; \mathrm{C}_{3}: \mathrm{C}_{30} \mathrm{H}_{28} \mathrm{Cu}_{2} \mathrm{~N}_{4} \mathrm{O}_{6}$. The proposed structures of the complexes mentioned above are depicted in Figure 1.

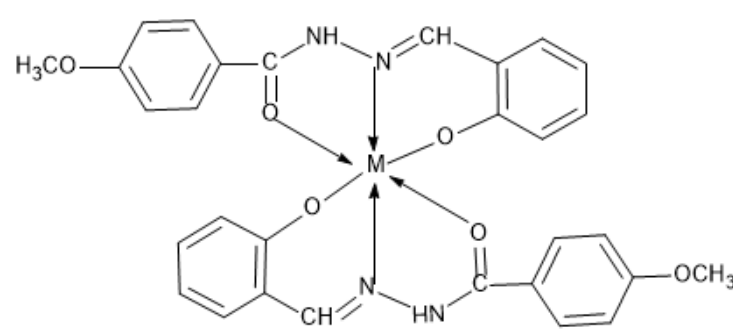

(a)

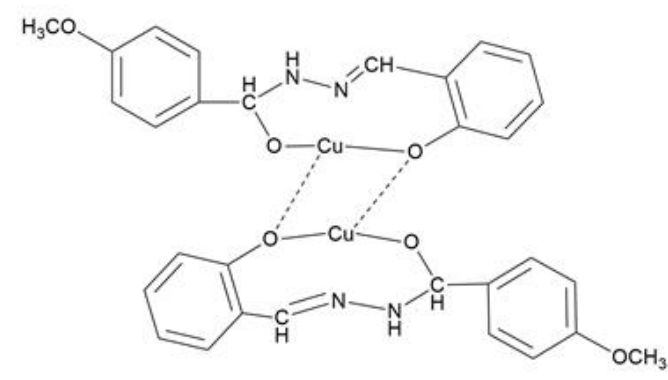

(b)

Figure 1. (a) Proposed structure of metal complexes $\mathrm{C}_{1}$ and $\mathrm{C}_{2}$; (b) Proposed structure of metal complex $\mathrm{C}_{3}$. 


\subsection{Biological studies.}

\subsubsection{In vitro antimicrobial studies.}

The method used for antibacterial activity was the Agar Well-Diffusion method. The bacteria were inoculated on the surface of nutrient agar. Agar well was prepared with the help of a sterilized cork borer with $10 \mathrm{~mm}$ diameter. The various concentrations $(20,40,60,80,100$ $\mu \mathrm{gL}^{-1}$ ) of HBMB and its metal complexes were inoculated in the wells prepared on the agar plates. The plates were incubated for $24 \mathrm{~h}$ for bacteria. To clarify the effect of DMSO for its antimicrobial activity by agar plate assay, separate studies were carried out with DMSO and showed no activity against any bacteria. The diameter of the inhibition zone was measured in $\mathrm{cm}$, and the results were recorded.

\subsubsection{Antiproliferative activities against human cancer cell lines (MCF-7 and HT -29).}

The compounds' potential cytotoxicity was tested using the method of Skehan and Storeng [16-18]. The cytotoxicity of HBMB and its metal complexes were assessed using a cell death assay based on the detection of cells by sulforhodamine-B (SRB) assay. The cells were inoculated into 96 well microtiter plates in $90 \mu \mathrm{L}$ at plating densities of $5 \times 10^{3}$ cells per well depending on individual cell lines' doubling time. Cell inoculation was done and the microtiter plates were incubated for $24 \mathrm{~h}$ before the addition of standard. After $24 \mathrm{~h}$, one plate of each cell line was fixed in situ with trichloroacetic acid (TCA) to represent a measurement of the cell population for each cell line at the time of drug addiction. HBMB and its metal complexes were dissolved in an appropriate solvent 400-fold in the expected final maximum test concentration and stored frozen before use. An aliquot of frozen concentrate was drawn and diluted to 10 times the desired final maximum test concentration with a complete medium containing test article at a concentration of $10^{-3} \mathrm{M}$. Additionally, three 10 -fold serial dilutions were prepared to provide a total of four drug concentrations plus control. Aliquots of $10 \mu \mathrm{L}$ of the above different drug dilutions were added to the appropriate microtiter wells already containing $90 \mu \mathrm{L}$ of the medium, resulting in the desired final drug concentration.

The plates were incubated for $48 \mathrm{~h}$ after adding the test compounds, and the addition of cold TCA quenched the assay. Cells were fixed in situ by the slow addition of $50 \mu \mathrm{L}$ of cold $30 \%(w / v)$ TCA (final concentration, 10\% TCA) and incubated for $60 \mathrm{~min}$ at $4{ }^{\circ} \mathrm{C}$. The supernatant was discarded, and the plates were washed five times with tap water and air-dried. Sulforhodamine B (SRB) solution $(50 \mu \mathrm{L})$ at $0.4 \%(\mathrm{w} / \mathrm{v})$ in $1 \%$ acetic acid has been added to each well, and the plates were incubated for $20 \mathrm{~min}$ at room temperature. After staining, the unbound dye was recovered, and residual dye was removed by washing five times with $1 \%$ acetic acid. The plates were air-dried. The bound stain was subsequently eluted with a $10 \mathrm{mM}$ trizma base, and the electronic absorbance was measured on an Elisa plate reader at a wavelength of $540 \mathrm{~nm}$ with $690 \mathrm{~nm}$ reference wavelength. Percentage growth was calculated on a plate by plate basis for test wells relative to control wells. All experiments have repeated a minimum of three times, with each experiment done in four replicates. Adriamycin served as the positive control compound in the cytotoxic assay. The relation between percentage growth control and drug concentration is plotted to get the breast tumor cell line's survival curve for each compound. 


\section{Results and Discussion}

The ligand HBMB and the metal complexes synthesized were stable at room temperature and soluble in common solvents like methanol, ethanol, DMSO, etc. The elemental analysis of ligand and the metal complexes were found in agreement with the proposed structure of ligand and the metal complexes and are listed in Table 1.

\section{1. ${ }^{1} \mathrm{H}-\mathrm{NMR}$ and mass spectral analysis.}

${ }^{1} \mathrm{H}-\mathrm{NMR}$ spectra of HBMB were recorded in DMSO-d6 to elucidate the structure of HBMB. A broad multiplet observed in the range $\delta 6.83-7.91 \mathrm{ppm}$ was assigned to aromatic protons of HBMB (Fig. 2). The signal that appears at $\delta 8.52 \mathrm{ppm}$ is due to azomethine proton. Two singlets at $\delta 11.51$ and $11.86 \mathrm{ppm}$ are assigned to $-\mathrm{OH}$ and $-\mathrm{NH}$ protons, respectively. The spectrum of HBMB also exhibited a singlet at $\delta 3.82 \mathrm{ppm}$, which is attributed to $-\mathrm{OCH}_{3}$ protons. Further, the formation of HBMB was confirmed using mass spectral analysis. The molecular ion peak of HBMB was noticed at $\mathrm{m} / \mathrm{z}=271.97$, which was in agreement with the theoretical value $(\mathrm{m} / \mathrm{z}=270.29)$. Similarly, the peak observed at $\mathrm{m} / \mathrm{z}=593.0121$ and 667.1655 corresponds to the mass value of $\mathrm{C}_{1}$ and $\mathrm{C}_{3}$, respectively. Furthermore, all the experimental mass values are in good agreement with the theoretically calculated values (Figs. S4 and S5).

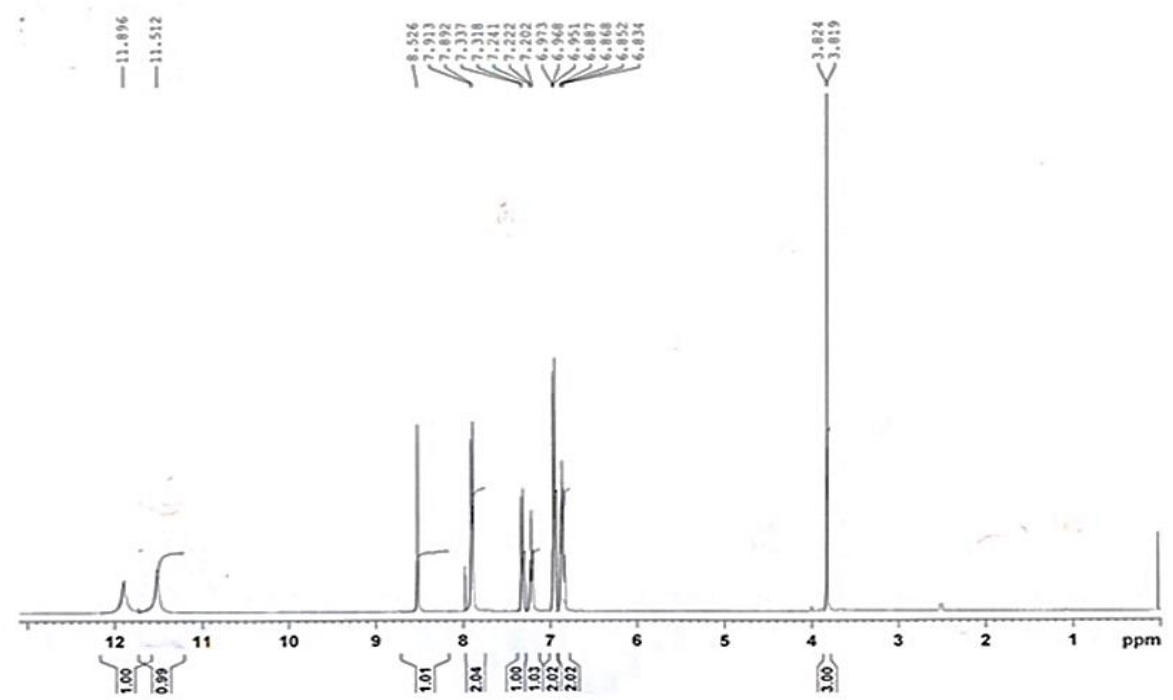

Figure 2. ${ }^{1} \mathrm{H}-\mathrm{NMR}$ spectrum of (E)-N'-(2-hydroxybenzylidene)-4-methoxybenzohydrazide (HBMB).

\subsection{FT-IR spectral analysis.}

FT-IR spectra of the HBMB and its metal complexes were compared as the bands are expected to get appeared, disappeared, or shifted during coordination (Table 1). The comparison of the FT-IR data of the ligand HBMB and its metal complexes confirmed that complexation has occurred, as significant shifts are observed in the band of azomethine group $v(-\mathrm{C}=\mathrm{N}-)$, carbonyl $v(\mathrm{C}=\mathrm{O})$ group, and protonated phenolic oxygen atom [19]. The FT-IR of HBMB and its representative metal complex $\left(\mathrm{C}_{1}\right)$ are shown in Fig. 3. The band in the region $3415 \mathrm{~cm}^{-1}$ is due to intramolecular -OH bonding of phenolic group in HBMB is not observed in the complexes $\left(\mathrm{C}_{1}-\mathrm{C}_{3}\right)$, clearly indicates that the ligand was coordinated with the metal center in its deprotonated form. On the other hand, the ligand HBMB exhibits a strong band at 1618 $\mathrm{cm}^{-1}$ due to the formation of $v(-\mathrm{C}=\mathrm{N}-)$ azomethine group, which gets shifted to the region $1598-1605 \mathrm{~cm}^{-1}$ in the complexes $\left(\mathrm{C}_{1}-\mathrm{C}_{3}\right)$, representing complexation of azomethine nitrogen to the metal ion forming a metal-nitrogen bond. On coordination, the electron density of 
nitrogen on azomethine linkage gets reduced due to the donation of lone pair of electrons of nitrogen to the vacant d-orbitals of transition metal centers, consequently lowers the $v(-\mathrm{C}=\mathrm{N}-$ ) absorption [20]. A sharp band in the region of $1662 \mathrm{~cm}^{-1}$ due to $v(\mathrm{C}=\mathrm{O})$ stretch of ligand was shifted to 1622 and $1629 \mathrm{~cm}^{-1}$, which suggests that ligand is in the keto form in $\mathrm{C}_{1}$ and $\mathrm{C}_{2}$ metal complexes. However, $v(\mathrm{C}=\mathrm{O})$ stretch is not observed in $\mathrm{C}_{3}$ complex. The FT-IR of the HBMB shows a medium intensity band at $3290 \mathrm{~cm}^{-1}$ due to $v(-\mathrm{NH})$ stretching vibration, shifted to a lower frequency in metal complexes $\left(\mathrm{C}_{1}-\mathrm{C}_{3}\right)$ (Figs. S1 and $\mathrm{S} 2$ ).

The band observed at $1224 \mathrm{~cm}^{-1}$ in the ligand may be assigned to $v(\mathrm{C}-\mathrm{O})$ stretching vibration of the phenolic group. Displacement of this band to the higher frequency is probably due to an increase in $\mathrm{C}-\mathrm{O}$ band strength on extended delocalization of $\pi$ system of azine moiety. Two or three bands appearing in the range of $1535-1562 \mathrm{~cm}^{-1}$ are assigned to various stretching modes such as $v(\mathrm{C}=\mathrm{C})$ vibration. The $\mathrm{N}-\mathrm{N}$ stretching vibrations are found in between 1110 and $1140 \mathrm{~cm}^{-1}$. However, the complexation was also supported by the appearance of the weak bands of $v(M-O)$ and $v(M-N)$, which were observed in the range of 443-448 and 424-427 $\mathrm{cm}^{-1}$ [21].

The simulated FT-IR spectra for HBMB and the three metal complexes were calculated as mentioned in Table 1.

Table 1. Important stretching frequencies observed in the HBMB and its complexes (in $\left.\mathrm{cm}^{-1}\right)$.

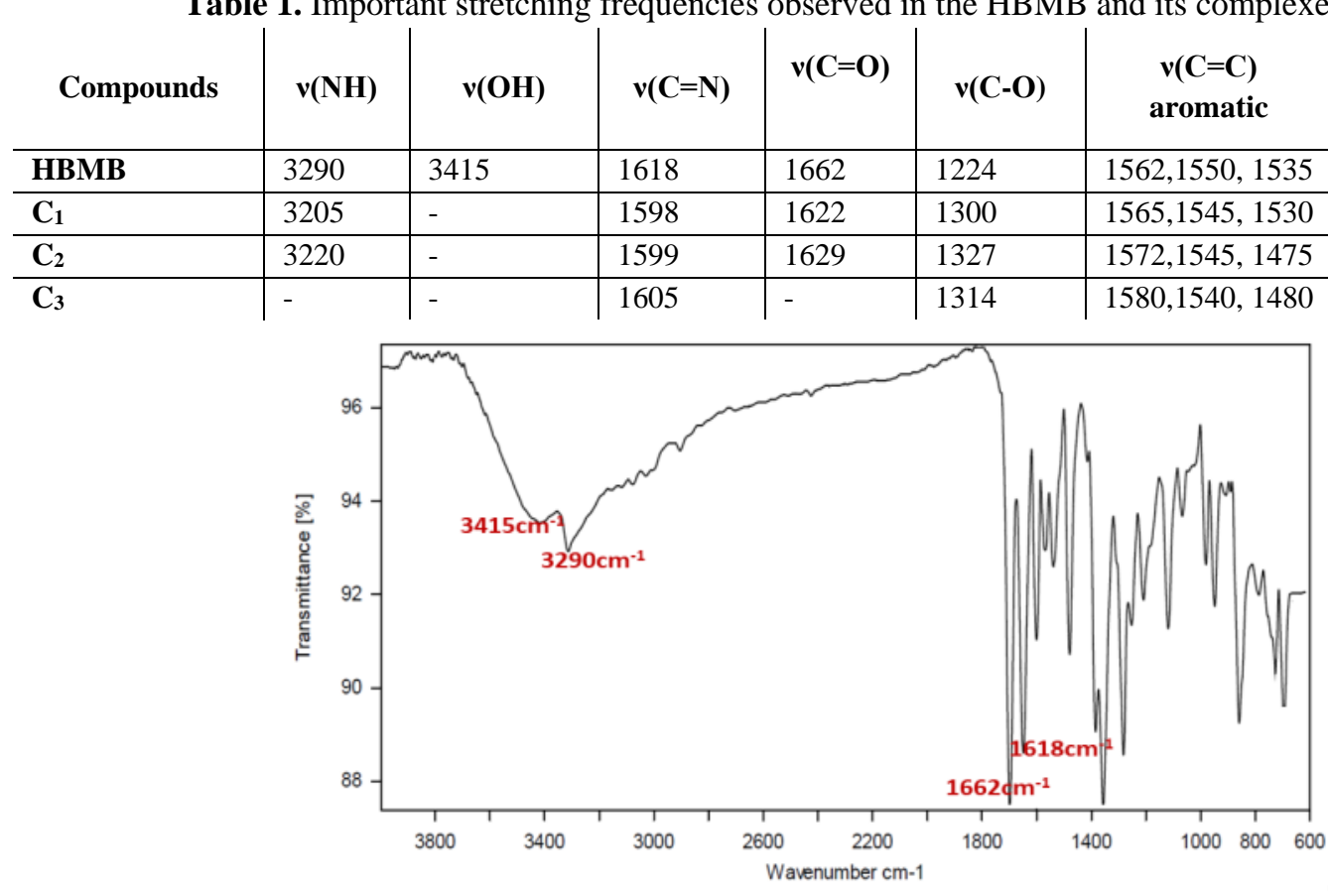

(a)

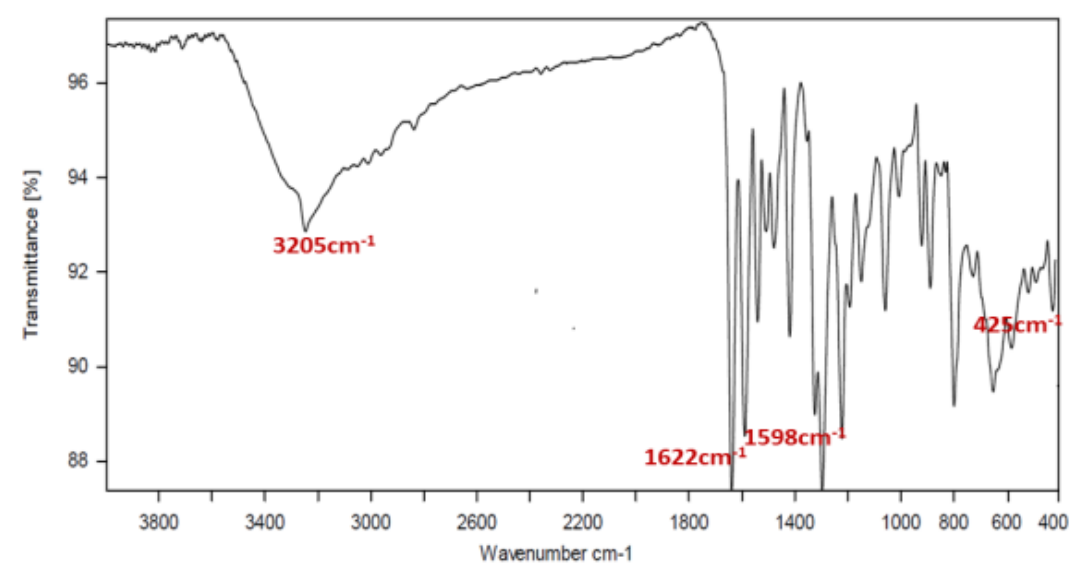

Figure 3. FT-IR spectra of (a) HBMB; (b) complex $\mathrm{C}_{1}$. 


\subsection{UV-Visible spectral investigations.}

UV-Visible spectroscopic studies were carried out to investigate the photophysical properties of HBMB and its metal complexes. The absorption spectra are recorded in DMSO solution. The peaks observed at 287 and $291 \mathrm{~nm}$ in the spectrum of HBMB suggests the presence of $\pi \rightarrow \pi^{*}$ and $n \rightarrow \pi^{*}$ transitions within the aromatic ring of the ligand moiety. These peaks are shifted slightly to the higher frequencies in complexes [22]. Another peak observed between 300 and $310 \mathrm{~nm}$ could be attributed to the $n \rightarrow \pi^{*}$ transition due to the azomethine group. These are shifted to lower frequencies in the case of metal complexes [23]. The peaks observed at 283, 296, and $286 \mathrm{~nm}$ are assigned to $\mathrm{n} \rightarrow \pi^{*}$ transitions in $\mathrm{C}_{1}, \mathrm{C}_{2}$, and $\mathrm{C}_{3}$, respectively [24]. The simulated UV-Vis spectra for the ligand and its metal complexes are represented in Figure 4.

The magnetic moment obtained at room temperature for $\mathrm{C}_{1}$ and $\mathrm{C}_{2}$ complexes reported herein has magnetic moment values $\sim 5.99 \mathrm{BM}$ and $\sim 3.75 \mathrm{BM}$, respectively, which is in good agreement with the octahedral complexes [25]. The room temperature magnetic moment value $\sim 1.66 \mathrm{BM}$ for the $\mathrm{C}_{3}$ complex is normally observed for square planar geometry [26].

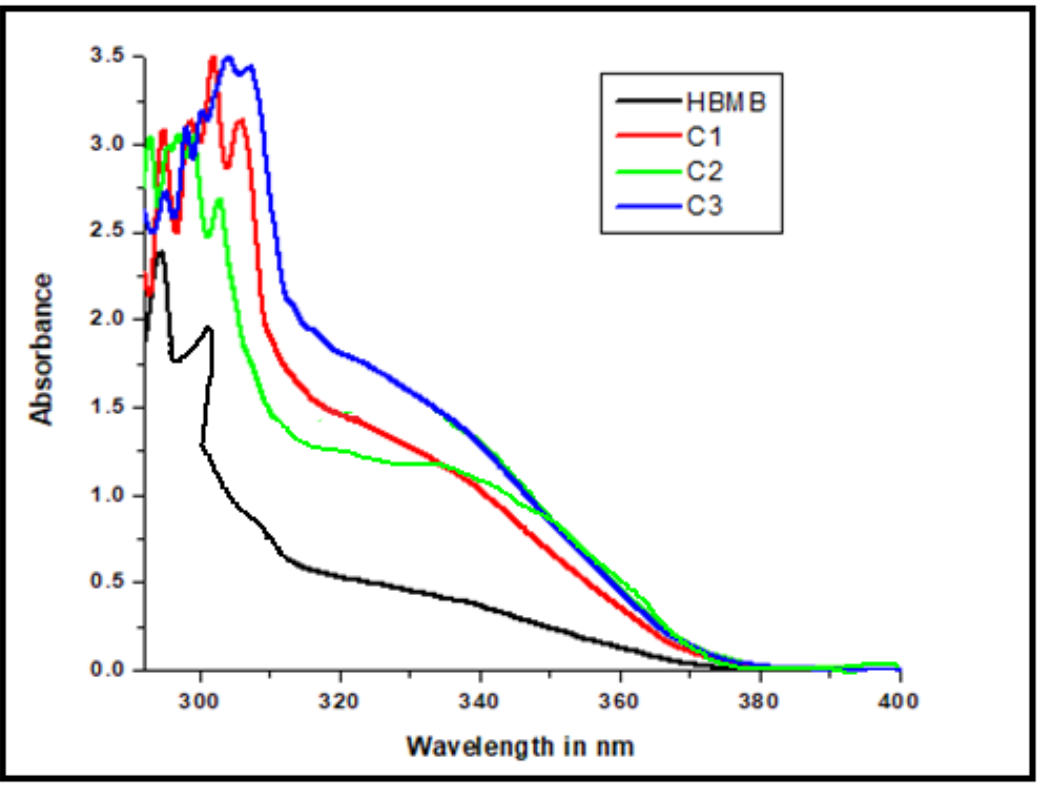

Figure 4. UV-Vis spectra of HBMB and its metal complexes in DMSO solution.

Table 2. Showing the steps involved in the thermal degradation of metal complexes.

\begin{tabular}{l|l|l|l|l|l}
\multirow{2}{*}{ Compound } & \multicolumn{2}{|l|}{ Thermogravimetry (TG) } & \multicolumn{2}{l}{ Mass loss (\%) } & \multicolumn{2}{l}{$\begin{array}{l}\text { Decomposition } \\
\text { loss }\end{array}$} \\
& \multicolumn{2}{|l|}{ product } \\
\cline { 2 - 5 } & Stage & Temp (oC) & Found & Calculated & \\
\hline C1 & I & $25-218$ & 8.25 & 9.40 & $-2 \mathrm{OCH}_{3}$ \\
& II & $218-412$ & 32.12 & 33.69 & $-2 \mathrm{C}_{8} \mathrm{H}_{10} \mathrm{~N}_{2}$ \\
& & $412-560$ & 27.01 & 7.81 & $-\mathrm{C}_{6} \mathrm{H}_{4}$ \\
& & $560-900$ & 41.08 & 39.98 & Fraction of Ligand \\
\hline C2 & I & $25-298$ & 9.07 & 10.45 & $-2 \mathrm{OCH}_{3}$ \\
& II & $298-429$ & 30.43 & 30.59 & $-\mathrm{C}_{13} \mathrm{H}_{8}$ \\
& & $429-818$ & 33.01 & 32.15 & $-\mathrm{C}_{7} \mathrm{H}_{6} \mathrm{~N}_{2}$ \\
& & $818-900$ & 13.24 & & Fraction of Ligand \\
\hline C3 & I & $25-298$ & 8 & 9.28 & $-2 \mathrm{OCH}_{3}$ \\
& II & $298-429$ & 27.71 & 27.72 & $-2 \mathrm{C}_{13} \mathrm{H}_{8}$ \\
& & $429-818$ & 32.05 & 32.64 & $\mathrm{C}_{9} \mathrm{H}_{8} \mathrm{~N}_{2}$ \\
& & $818-900$ & 11.20 & 11.33 & Fraction of Ligand
\end{tabular}




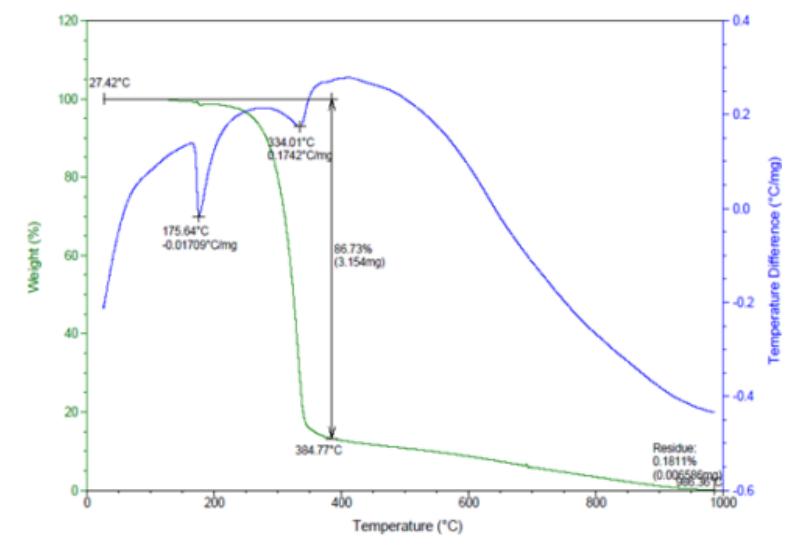

(a)

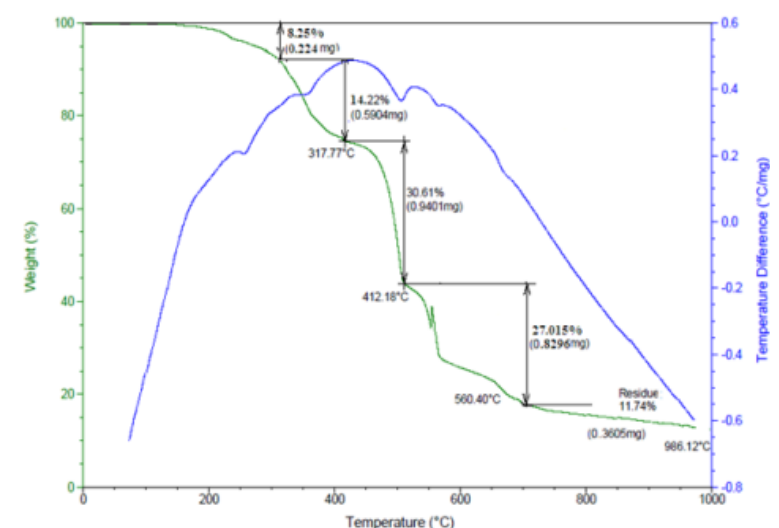

(b)

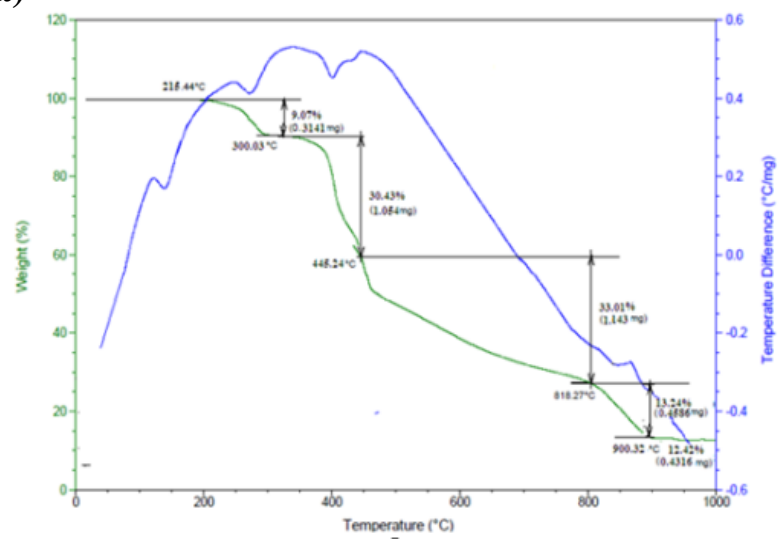

(c)

Figure 5. TGA and DSC pictograms of the (a) $\mathrm{C}_{1} ;(\mathbf{b}) \mathrm{C}_{2}$ and $\mathrm{C}_{3}$ complexes.

\subsection{Thermal analysis.}

The thermal stability profiles of all the synthesized complexes $\left(\mathrm{C}_{1}-\mathrm{C}_{3}\right)$ were investigated by TGA and DSC studies (Figure 5). Table 2 summarizes the recorded TGA/DSC curves of all the complexes. The complexes $\left(\mathrm{C}_{1}-\mathrm{C}_{3}\right)$ undergo two-step decomposition processes. The initial weight loss occurs in-between temperature range of $25-298{ }^{\circ} \mathrm{C}$ due to loss of two $-\mathrm{OCH}_{3}$ groups of $\mathrm{HBMB}$, whereas the second step shows gradual loss of a remaining fraction of ligand moieties at various temperature ranges leaving behind stable metal oxides of $\mathrm{Mn}(\mathrm{II}), \mathrm{Ni}(\mathrm{II})$ and $\mathrm{Cu}(\mathrm{II})$ respectively.

\subsection{In vitro antibacterial and antifungal activities.}

It has been observed that the HBMB is less active against Gram-positive bacteria (Staphylococcus aureus), Gram-negative bacteria (Escherichia coli), and fungal strain (Aspergillus niger). But its metal complexes $\left(\mathrm{C}_{1}-\mathrm{C}_{3}\right)$ are potent against the tested organisms. In the case of complexes, $C_{3}$ complex is more active as compared to the $\mathrm{C}_{1}$ and $\mathrm{C}_{2} . \mathrm{C}_{2}$ complex is moderately active against bacteria Staphylococcus aureus and fungal strain (Aspergillus niger) and highly active against Escherichia coli. Simultaneously, the $\mathrm{C}_{1}$ complex is moderately active against bacteria Staphylococcus aureus, Escherichia coli, and fungal strain (Aspergillus niger). As the concentration of HBMB and its metal complexes $\left(\mathrm{C}_{1}-\mathrm{C}_{3}\right)$ increases, microbial activities also increase. Among the microorganisms, Escherichia coli has been found to be more sensitive than Staphylococcus aureus. The observed trend in activity against Staphylococcus aureus and Escherichia coli can be summarized as 
$\mathrm{HBMB}<\mathrm{C}_{1}<\mathrm{C}_{2}<\mathrm{C}_{3}$

Metal complexes exhibited good antibacterial and antifungal activity, than HBMB $\mathrm{Cu}$ (II) complex exhibited the highest antimicrobial activity among all tested compounds. Results were compared with standard antibiotic drugs Ampicillin and Fluconazole Table 3.

Table 3. In vitro antibacterial screening activity of $\mathrm{HBMB}$ and complexes $\mathrm{C}_{1}-\mathrm{C}_{3}$.

\begin{tabular}{|c|c|c|c|c|c|}
\hline Name & Conc. $\mu \mathrm{g} / \mathrm{L}$ & B. Subtilis & E. Coli & A. flavus & A. niger \\
\hline \multirow[t]{2}{*}{ HBMB } & 0.5 & $+\mathrm{ve}$ & + ve & $+\mathrm{ve}$ & $+\mathrm{ve}$ \\
\hline & 1 & $+\mathrm{ve}$ & $+\mathrm{ve}$ & $+\mathrm{ve}$ & $++\mathrm{ve}$ \\
\hline \multirow[t]{2}{*}{ C1 } & 0.5 & + ve & $+\mathrm{ve}$ & $+\mathrm{ve}$ & $++\mathrm{ve}$ \\
\hline & 1 & $++\mathrm{ve}$ & $++\mathrm{ve}$ & $++\mathrm{ve}$ & $++\mathrm{ve}$ \\
\hline \multirow[t]{2}{*}{$\mathrm{C2}$} & 0.5 & ++ ve & +++ ve & +++ ve & $+++\mathrm{ve}$ \\
\hline & 1 & +++ ve & +++ ve & $+++\mathrm{ve}$ & +++ ve \\
\hline \multirow[t]{2}{*}{$\mathbf{C 3}$} & 0.5 & $+\mathrm{ve}$ & $+\mathrm{ve}$ & $+\mathrm{ve}$ & $++\mathrm{ve}$ \\
\hline & 1 & ++ ve & +++ ve & $++\mathrm{ve}$ & $++\mathrm{ve}$ \\
\hline \multicolumn{2}{|c|}{$\begin{array}{l}\text { Inhibition : - ve =Inactive, } \\
(\text { Less than } 0.5 \mathrm{~cm}) \\
++ \text { ve }=\text { Moderately active, } \\
(1 \text { to } 2 \mathrm{~cm})\end{array}$} & $\begin{array}{r}\quad(0.5- \\
+++ \text { ve }= \\
(\text { more than }\end{array}$ & $\begin{array}{l}\text { Weakly ac } \\
\text { active }\end{array}$ & & \\
\hline
\end{tabular}

\subsection{Effect of $H B M B$ and its complexes (C1-C3) on antiproliferative activity.}

Average values for \% control growth for the cell line MCF-7 and HT-29 are tabulated in Table 4, cytotoxicity for the cell line MCF-7 and HT-29 are as shown in Table 5, and growth curve for human breast cancer cell line MCF-7 and HT-29 for HBMB and its complexes are represented in Figure 6.

Predicting anticancer activity based on average values for \% control growth, HBMB is inactive at all concentrations $\left(10^{-4}, 10^{-5}, 10^{-6}\right.$, and $\left.10^{-7} \mathrm{M}\right)$ with both the human cancer cell lines. Out of three complexes, the $\mathrm{C}_{3}$ complex is showing potent activity. The order of anticancer activity for series of metal complexes is as follows $\mathrm{C}_{3}>\mathrm{C}_{2}>\mathrm{C}_{1}$. Estimations based on GI50 values exhibit that HBMB is inactive to both human cancer cell lines such as breast (MCF-7) and colon (HT-29) with GI50 of $52.2 \mu \mathrm{M}$ and $92.2 \mu \mathrm{M}$, respectively. In comparison, the $\mathrm{C}_{3}$ complex exhibits potent in vitro anticancer activity against both the tested cancer cell lines with an $\mathrm{IC}_{50}$ value of $<0.1 \mu \mathrm{M}$, which is comparable to Adriamycin with $\mathrm{IC}_{50}$ of $<0.1 \mu \mathrm{M}$. $\mathrm{C}_{1}$ shows moderate activity against the MCF-7 cancer cell line with an $\mathrm{IC}_{50}$ value of $11.1 \mu \mathrm{M}$ and resistance to the colon (HT-29) cell line with an $\mathrm{IC}_{50}$ value of $84.9 \mu \mathrm{M}$. The $\mathrm{C} 2$ complex also exhibits potent in vitro anticancer activity against the MCF-7 cell line with an $\mathrm{IC}_{50}$ value of $<0.1 \mu \mathrm{M}$ and weak activity for a colon cell line with an $\mathrm{IC}_{50}$ value of $<0.1 \mu \mathrm{M}$.

Table 4. Average values for \% control growth for the MCF-7 and HT-29 cell lines.

\begin{tabular}{|c|c|c|c|c|c|c|}
\hline \multirow[t]{2}{*}{ Compounds } & \multicolumn{3}{|c|}{$\begin{array}{l}\mu M \text { drug concentration for the cell line } \\
\text { MCF-7 }\end{array}$} & \multicolumn{3}{|c|}{$\mu \mathrm{M}$ drug concentration for the cell line HT-29 } \\
\hline & LC50 & TGI & GI50* & LC50 & TGI & GI50* \\
\hline HBMB & $>100$ & $>100$ & 52.2 & $>100$ & $>100$ & 92.2 \\
\hline C1 & $>100$ & $>100$ & 11.1 & $>100$ & $>100$ & 84.9 \\
\hline $\mathbf{C 2}$ & $>100$ & $>100$ & $<0.1$ & $>100$ & $<0.1$ & $<0.1$ \\
\hline $\mathrm{C3}$ & $>100$ & 49.6 & $<0.1$ & $>100$ & 98.2 & 35.0 \\
\hline ADR & $>100$ & 45.7 & $<0.1$ & $>100$ & 22.2 & $<0.1$ \\
\hline
\end{tabular}


Table 5. Drug concentrations calculated from a graph $(\mu \mathrm{M})$.

\begin{tabular}{|c|c|c|c|c|c|c|}
\hline \multirow[t]{2}{*}{ Compounds } & \multicolumn{3}{|c|}{$\begin{array}{l}\mu M \text { drug concentration for the cell line } \\
\text { MCF-7 }\end{array}$} & \multicolumn{3}{|c|}{$\mu M$ drug concentration for the cell line HT-29 } \\
\hline & LC50 & TGI & GI50* & LC50 & TGI & GI50* \\
\hline HBMB & $>100$ & $>100$ & 52.2 & $>100$ & $>100$ & 92.2 \\
\hline $\mathbf{C}_{1}$ & $>100$ & $>100$ & 11.1 & $>100$ & $>100$ & 84.9 \\
\hline $\mathrm{C}_{2}$ & $>100$ & $>100$ & $<0.1$ & $>100$ & $<0.1$ & $<0.1$ \\
\hline $\mathrm{C}_{3}$ & $>100$ & 49.6 & $<0.1$ & $>100$ & 98.2 & 35.0 \\
\hline ADR & $>100$ & 45.7 & $<0.1$ & $>100$ & 22.2 & $<0.1$ \\
\hline
\end{tabular}

Value $*$ GI50 of $<5 \mu \mathrm{M}$ Super active, 5-15 $\mu \mathrm{M}$ Moderately active, 15-40 $\mu \mathrm{M}$ Weakly active, 31-100 $\mu \mathrm{M}$ Resistant, $>100 \mu \mathrm{M}$ Inactive

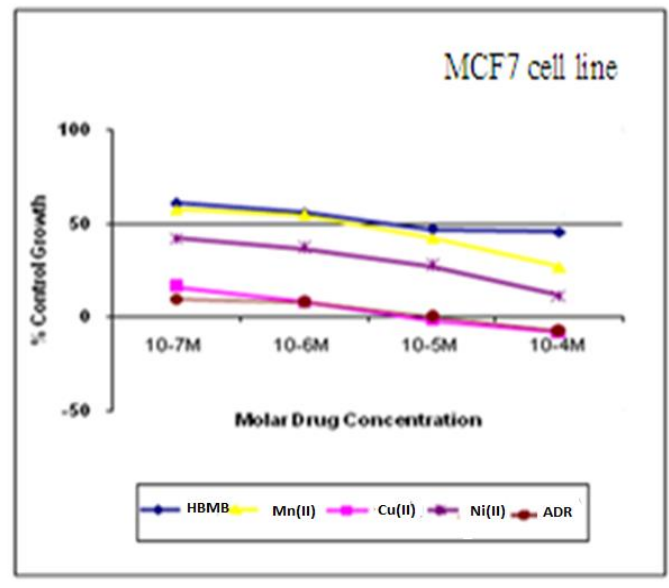

(a)

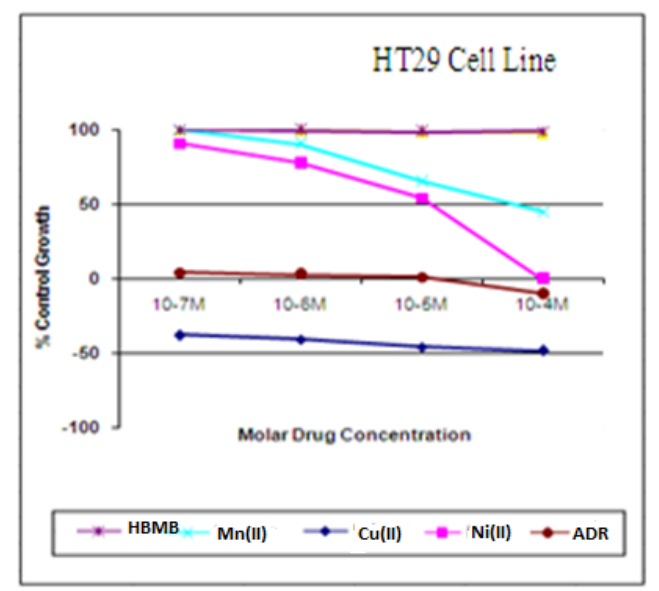

(b)

Figure 6. Graphs representing the growth inhibition against (a) MCF-7 breast cancer cell; (b) HT-29 colon cancer cell line when treated with HBMB and its metal complexes.

\section{Conclusions}

In summary, the series of complexes $\mathrm{Mn}(\mathrm{II}), \mathrm{Ni}(\mathrm{II})$, and $\mathrm{Cu}$ (II) were successfully synthesized using a Schiff base ligand HBMB. The molecular structure of HBMB ligand and its metal complexes $\left(\mathrm{C}_{1}-\mathrm{C}_{3}\right)$ has been determined using UV-Vis, FT-IR, ${ }^{1} \mathrm{H}-\mathrm{NMR}$, mass spectroscopy, and based on elemental analysis conductance data and TGA techniques. HBMB behaves as a tridentate ligand and reacts with metal ions to yield mononuclear complexes $\left(\mathrm{C}_{1}\right.$ $\mathrm{C}_{3}$ ). The ligand and complexes' electronic absorption was investigated in DMSO- $\mathrm{d}_{6}$ solution, which exhibits that the bands shifted to longer wavelength in the complexes are due to the ligand coordination with the metal ions. The synthesized compounds were then investigated for their cytotoxicity using MCF-7 and HT-29 cancer cell lines. Among all the compounds, $\mathrm{C}_{3}$ and $\mathrm{C}_{2}$ displayed considerable antiproliferative effects. The anticancer activity results also revealed that complexes $\mathrm{C}_{3}$ and $\mathrm{C}_{2}$ have effective cytotoxic power against cancer cell lines. The ligand HBMB and its metal complexes are further studied for their antimicrobial activities against Gram-positive bacteria (Staphylococcus aureus), Gram-negative bacteria (Escherichia coli), and fungal strain (Aspergillus niger). The study reveals that metal complexes show good antimicrobial activities as compare to HBMB. The information mentioned above could be useful in complementing the experimental data as the starting point in developing new therapeutic drugs based on these molecules.

\section{Funding}

This research received no external funding. 


\section{Acknowledgments}

The authors are thankful to the Director, Institute of Sciences, Mumbai, for providing analytical facilities. P.A.U. is thankful to the Principal of N. K. Orchid College of Engineering and Technology, Solapur. S.P.K. gratefully thanks the Director of Amrita Vishwa Vidyapeetham, Mysuru Campus, for facilitating infrastructure support.

\section{Conflicts of Interest}

The authors declare no conflict of interest regarding the publication of this paper.

\section{References}

1. Martin, H.L.; Smith, L.; Tomlinson, D.C. Multidrug-resistant breast cancer: current perspectives. Breast Cancer (London) 2014, 6, 1, https://doi.org/10.2147/BCTT.S37638.

2. Masoud, V.; Pagès, G. Targeted therapies in breast cancer: New challenges to fight against resistance. World J. Clin. Oncol. 2017, 8, 120-134, https://doi.org/10.5306/wjco.v8.i2.120.

3. Jia, P.; Ouyang, R.; Cao, P.; Tong, X.; Zhou, X.; Lei, T.; Zhao, Y.; Guo, N.; Chang, H.; Miao, Y.; Zhou, S. Review: recent advances and future development of metal complexes as anticancer agents. J. Coord. Chem. 2017, 70, 2175-2201, https://doi.org/10.1080/00958972.2017.1349313.

4. Tong, C.W.S.; Wu, M.; Cho, W.C.S.; To, K.K.W. Recent Advances in the Treatment of Breast Cancer. Front. Oncol. 2018, 8, 227, https://doi.org/10.3389/fonc.2018.00227.

5. More, M.S.; Joshi, P.G.; Mishra, Y.K.; Khanna, P.K. Metal complexes driven from Schiff bases and semicarbazones for biomedical and allied applications: a review. Materials Today Chemistry 2019, 14, https://doi.org/10.1016/j.mtchem.2019.100195.

6. Sheikh, R.A.; Wani, M.Y.; Shreaz, S.; Hashmi, A.A. Synthesis, characterization and biological screening of some Schiff base macrocyclic ligand based transition metal complexes as antifungal agents. Arabian Journal of Chemistry 2016, 9, S743-S751, https://doi.org/10.1016/j.arabjc.2011.08.003.

7. Shokohi-pour, Z.; Chiniforoshan, H.; Momtazi-borojeni, A.A.; Notash, B. A novel Schiff base derived from the gabapentin drug and copper (II) complex: Synthesis, characterization, interaction with DNA/protein and cytotoxic activity. J. Photochem. Photobiol. B: Biol. 2016, 162, 34-44, https://doi.org/10.1016/j.jphotobiol.2016.06.022.

8. More, M.S.; Joshi, P.G.; Mishra, Y.K.; Khanna, P.K. Metal complexes driven from Schiff bases and semicarbazones for biomedical and allied applications: a review. Materials Today Chemistry 2019, 14, 100195, https://doi.org/10.1016/j.mtchem.2019.100195.

9. Festus, C.; Okafor, S.N.; Ekennia, A.C. Heteroleptic Metal Complexes of a Pyrimidinyl Based Schiff Base Ligand Incorporating 2,2'-Bipyridine Moiety: Synthesis, Characterization, and Biological Studies. Frontiers in Chemistry 2019, 7, 862, https://doi.org/10.3389/fchem.2019.00862.

10. Turan, N.; Buldurun, K.; Çolak, N.; Özdemir, İ. Preparation and spectroscopic studies of Fe(II), Ru(II), Pd(II) and $\mathrm{Zn}$ (II) complexes of Schiff base containing terephthalaldehyde and their transfer hydrogenation and Suzuki-Miyaura coupling reaction. Open Chemistry 2019, 17, 571-580, https://doi.org/10.1515/chem-20190074.

11. Devi, J.; Yadav, M.; Kumar, A.; Kumar, A. Synthesis, characterization, biological activity, and QSAR studies of transition metal complexes derived from piperonylamine Schiff bases. Chemical Papers 2018, 72, 24792502, https://doi.org/10.1007/s11696-018-0480-0.

12. El-Sonbati, A.Z.; Mahmoud, W.H.; Mohamed, G.G.; Diab, M.A.; Morgan, S.M.; Abbas, S.Y. Synthesis, characterization of Schiff base metal complexes and their biological investigation. Appl. Organomet. Chem. 2019, 33, e5048, https://doi.org/10.1002/aoc.5048.

13. Vinusha, H.; Prasad, S.; Ramu, R.; Shirahatti, P.; Prasad, N.; Begum, M. Chemical Synthesis, Spectral Characterization and Biological Investigations of Novel Triazole-Based Schiff Base Ligand and its Transition Complexes. Letters in Applied NanoBioScience 2020, 9, 1372-1388, https://doi.org/10.33263/LIANBS93.13721388.

14. Amblard, F.; Zhou, S.; Liu, P.; Yoon, J.; Cox, B.; Muzzarelli, K.; Kuiper, B.D.; Kovari, L.C.; Schinazi, R.F. Synthesis and antiviral evaluation of novel peptidomimetics as norovirus protease inhibitors. Bioorg. Med. Chem. Lett. 2018, 28, 2165-2170, https://doi.org/10.1016/j.bmcl.2018.05.012. 
15. El-Faham, A.; Farooq, M.; Khattab, S.N.; Abutaha, N.; Wadaan, M.A.; Ghabbour, H.A.; Fun, H.-K. Synthesis, Characterization, and Anti-Cancer Activity of Some New N'-(2-Oxoindolin-3-ylidene)-2propylpentane hydrazide-hydrazones $\quad$ Derivatives. $\quad$ Molecules 20, https://doi.org/10.3390/molecules200814638.

16. Ambika, S.; Manojkumar, Y.; Arunachalam, S.; Gowdhami, B.; Meenakshi Sundaram, K.K.; Solomon, R.V.; Venuvanalingam, P.; Akbarsha, M.A.; Sundararaman, M. Biomolecular Interaction, Anti-Cancer and AntiAngiogenic Properties of Cobalt(III) Schiff Base Complexes. Scientific Reports 2019, 9, 1-14, https://doi.org/10.1038/s41598-019-39179-1.

17. Vichai, V.; Kirtikara, K. Sulforhodamine B colorimetric assay for cytotoxicity screening. Nat. Protoc. 2006, 1, 1112-1116, https://doi.org/10.1038/nprot.2006.179.

18. Skehan, P.; Storeng, R.; Scudiero, D.; Monks, A.; McMahon, J.; Vistica, D.; Warren, J.T.; Bokesch, H.; Kenney, S.; Boyd, M.R. New Colorimetric Cytotoxicity Assay for Anticancer-Drug Screening. JNCI: Journal of the National Cancer Institute 1990, 82, 1107-1112, https://doi.org/10.1093/jnci/82.13.1107.

19. Vinusha, H.M.; Kollur, S.P.; Revanasiddappa, H.D.; Ramu, R.; Shirahatti, P.S.; Nagendra Prasad, M.N.; Chandrashekar, S.; Begum, M. Preparation, spectral characterization and biological applications of Schiff base ligand and its transition metal complexes. Results in Chemistry 2019, 1, https://doi.org/10.1016/j.rechem.2019.100012.

20. Abdel-Rahman, L.H.; Abu-Dief, A.M.; El-Khatib, R.M.; Abdel-Fatah, S.M. Some new nano-sized Fe(II), $\mathrm{Cd}(\mathrm{II})$ and $\mathrm{Zn}$ (II) Schiff base complexes as precursor for metal oxides: Sonochemical synthesis, characterization, DNA interaction, in vitro antimicrobial and anticancer activities. Bioorg. Chem. 2016, 69, 140-152, https://doi.org/10.1016/j.bioorg.2016.10.009.

21. Omar, M.M.; Abd El-Halim, H.F.; Khalil, E.A.M. Synthesis, characterization, and biological and anticancer studies of mixed ligand complexes with Schiff base and 2,2'-bipyridine. Appl. Organomet. Chem. 2017, 31, e3724, https://doi.org/10.1002/aoc.3724.

22. Saranya, J.; Jone Kirubavathy, S.; Chitra, S.; Zarrouk, A.; Kalpana, K.; Lavanya, K.; Ravikiran, B. Tetradentate Schiff Base Complexes of Transition Metals for Antimicrobial Activity. Arabian Journal for Science and Engineering 2020, 45, 4683-4695, https://doi.org/10.1007/s13369-020-04416-7.

23. Khanmohammadi, H.; Amani, S.; Abnosi, M.H.; Khavasi, H.R. New asymmetric heptaaza Schiff base macrocyclic complex of Mn(II): Crystal structure, biological and DFT studies. Spectrochimica Acta Part A: Molecular and Biomolecular Spectroscopy 2010, 77, 342-347, https://doi.org/10.1016/j.saa.2010.02.001.

24. Prasad, K.S.; Kumar, L.S.; Chandan, S.; Naveen Kumar, R.M.; Revanasiddappa, H.D. Palladium(II) complexes as biologically potent metallo-drugs: Synthesis, spectral characterization, DNA interaction studies and antibacterial activity. Spectrochimica Acta Part A: Molecular and Biomolecular Spectroscopy 2013, 107, 108-116, https://doi.org/10.1016/j.saa.2013.01.013.

25. Yamada, S.; Takeuchi, A. The conformation and interconversion of schiff base complexes of nickel(II) and copper(II). Coord. Chem. Rev. 1982, 43, 187-204, https://doi.org/10.1016/S0010-8545(00)82096-2.

26. Prasad, K.S.; Pillai, R.R.; Shivamallu, C.; Prasad, S.K.; Jain, A.S.; Pradeep, S.; Armaković, S.; Armaković, S.J.; Srinivasa, C.; Kallimani, S.; Amachawadi, R.G.; Ankegowda, V.M.; Marraiki, N.; Elgorban, A.M.; Syed, A. Tumoricidal Potential of Novel Amino-1,10-phenanthroline Derived Imine Ligands: Chemical Preparation, Structure, and Biological Investigations. Molecules 2020, 25, 2865-2877, https://doi.org/10.3390/molecules25122865. 